\title{
Impact of Modernization on Gender Roles A study of Advocates in Muzaffar Garh
}

\author{
${ }^{1}$ Alamdar Hussain, ${ }^{2}$ Naveed Ahmad, ${ }^{3}$ Raghib Manzoor, ${ }^{3}$ Mehtab Hameed \\ ${ }^{1}$ Mphil Scholar NCBA\&E, Lahore, Pakistan \\ ${ }^{2}$ Department of Business Administration, Lahore Leads University, Pakistan \\ ${ }^{3} \mathrm{Ph}$.D Scholar Preston University, Islamabad, Pakistan \\ E-mail address: naveeddgk2010@gmail.com
}

Keywords: Modernization; Gender roles; Development; Advancement; Opinion Making; Educational Gap; Transition stage

\begin{abstract}
The present study has been conducted to view the impact of modernization on gender roles. This was a quantitative study. The researcher has selected the area of Muzaffar Garh, And one hundred Advocates of Muzaffar garh are respondents. The researcher has study the socialization, decision-making, choice of marriage and household duties. Gender roles have been changed at a great extent due to modernization. Education played an important role for the progress and change in gender roles. The question comes in mind that is modernization good or bad. It had changed traditional gender roles. Now females have equal right in decision making. Females have choice to marriage and equal opportunity in education, and have easily access to university. Socialization of children and liberty are influenced due to modernization. It is concluded that male and female both are doing work out of home and in the home, due to which there have been created a gap and socialization of children is influenced. Our morals, values have remained back and we are not thinking about it. Females have choice to marriage, and male do not feel any hesitation to do house work. Modernization, mass media, technology and education have played important role to change gender roles.
\end{abstract}

\section{INTRODUCTION}

Many researcher talks about human history, Humans are used tools and techniques for their survival. They satisfied their need for hunting animals and gathering, foraging of vegetables and other substance. In comparatively in human history, people are satisfied for their basic needs i.e. hunting, gathering, food, fishing etc. Now in industrialization society people are dependent on physical environment. Modernization is the process by which a society, social institutions become increasingly complex as the society move towards Industrialization. The concept of Modernization is a process where the social change is completely adopted by people in the shape of clothing, thinking, industrialization and urbanization. In the view of sociological thinkers it is a process of rationalization. When modernization increases in any society the individual of the society must replaces his family and community as a core unit of society. (Kendall, 2007).A second aspect of modernization is a loss of traditional ways of thinking due to this the old thinking no longer be survive. A third aspect of modernization is the growth of individual freedom and autonomy as Émile Durkheim $(1895 / 1962)$ we live in a society where we all are deviant. Now the question is modernization is good or bad? The answer is simple the according to researchers that modernization in the concept of functionalism is good and the dysfunctionlism stress the institution of society. Durkheim famous theory the Divion of Labor (DOL) Is the example of functionalism where the all personal work in organization works in order to maintain organization the same situation is for the society every individual play his role to maintained society. Durkheim suggested that in a capitalist society, with a complex division of labor, economic regulation would be needed to maintain order. He further said that society's process through different transition stages to stages of simple to 
complex is the process of rationalization and adaptation. Mansell and When (1998) contributed development has been

understood since second world war to contribution of economic growth, increased capita income and living of style, machineries, technology.

\section{Sociological Significance of the Topic}

According to sociological theories on modernization refers to process of transition stage from simple to complexity.

In developing countries these effects are going to appear now. In Pakistan and particularly southern Punjab, now female are more participating in education and employment? This would lead towards change in traditional gender roles of men and women. So the research has selected the topic "Impact of modernization on gender roles" to view the change in traditional gender roles in Muzaffer Garh.

\section{Objectives of the research}

This research aims to address the impact of modernization on gender roles by examining the housework pattern, gender roles, Childs education, child freedom, family socialization and marriage pattern in the family.

- To explore the impact of modernization on both duties of male and females.

- To explore the influence of Modernization on the socialization of young family member.

- To explore the Influence of Modernization on decision making.

\section{LITERATURE REVIEWS}

Fouad (2003) explained that industrialization and urbanization have affected the family type. The size of the family, which is composed of only parents and child. Young women have the freedom to marry and live with her husband outside her parent's house. The study of women decision-making power in Egypt found that it is depended on family type. Women, who live in a nuclear family and have high education and income, will jointly make a decision together with her husband.

Inglehart and Norris (2003) concluded that development brings social change and cultural change towards their individual. Moderanization brings changes in gender roles and shift greater change in the women involve in professionalism and also gain vote and elected through any constituency.

Mukai (2004) suggested the relation between modernization and culture integrated with one another but every culture of system sustains some values to influence society. As a result, each system has different processes or consequences that result from modernization.

Carpinelli (2009) Concluded, the different role of male and female in society, the gender roles are different in each society. These changes in gender role also affect the home, workplace, school. Now, men and women are more conscious of sexual harassment than ever. Whereas 20 years ago a woman who refused to have an affair with her boss may have had to quit, she now has other options.

Gean (2010) researched that the modernization in developing era effects women's education and increasing her role in society. The researcher finds that today women's are more powerful than man, women's are more freedom than ever, women's have full freedom to participate in any movements and also in election, the top level management also manage by women's today, the domestic violence are also decrease.

\section{RESEARCH METHODOLOGY}

In sociological research,methodology refers to the practices and techniques used to gather ,process ,manipulate and interpret information that can then be used to test ideas and theories about social life" (Singleton and Straits, 1998). 


\section{Universe/Population}

The universe of the present study consists of the all the Advocates of District court Muzaffar Garh working in January 2015.

\section{Sampling}

The researcher has used simple random sampling technique to data collection. By following this philosophy, the researcher has selected any one hundred advocates in which males and females both doing practice in District court Muzaffar Garh.

\section{Instrument for data collection}

Interview schedule with structured questions was preferred for data collection because of following reasons:

1. Interschedule with structured questions was used because it allows the researcher to get more relevant information about the topic.

2. Interview schedule was used because face-to-face interviews have the highest response rates and permit the longest questionnaire.

3. By using interview schedule, the researcher has face-to-face interaction and is able to read the face expressions of the respondents and could probe easily.

4. In face-to-face interaction, the researcher can use non-verbal clues and visual aids.

5. The completion rate is 100 percent .Because there is less probability to miss the response and responses are accorded in well manner.

\section{RESULTS AND DISCUSSION}

Table 1. Percentage distribution of respondents regarding their female family member's job.

\begin{tabular}{|c|c|c|}
\hline $\begin{array}{c}\text { Females members doing } \\
\text { job }\end{array}$ & Frequency & Percent \\
\hline yes & 44 & 44 \\
\hline No & 56 & 56 \\
\hline Total & 100 & 100 \\
\hline
\end{tabular}

This table shows that 56 percent respondents claimed that females family members are not doing job, 44 percent respondents claimed that their female family members are doing any job. The result of this table shows that modernization has changed gender roles and females are also doing work out of home. This table relates to the objective No.1 impact of modernization on both duties of both male and females.

Table 2 Percentage distribution of respondents with regards to their ideas about the university education of their daughter.

\begin{tabular}{|c|c|c|}
\hline $\begin{array}{c}\text { Allow daughter for } \\
\text { university education }\end{array}$ & Frequency & Percent \\
\hline yes & 78 & 78 \\
\hline No & 22 & 22 \\
\hline Total & 100 & 100 \\
\hline
\end{tabular}

This table shows that 78 percent respondents wish for their daughter get university education, 22 percent of respondents do not wish to get university education for their daughter. Now more people support for higher education of their daughters that is an effect of modernization. This table relates to the objective No.1 impact of modernization on both duties of male and females. 
Table 3 Percentage distribution of respondents regarding to their responsibility of child's education.

\begin{tabular}{|c|c|c|}
\hline $\begin{array}{c}\text { Responsible for child } \\
\text { education }\end{array}$ & Frequency & Percent \\
\hline Father & 23 & 23 \\
\hline Mother & 17 & 17 \\
\hline Both & 60 & 60 \\
\hline Total & 100 & 100 \\
\hline
\end{tabular}

This table shows that 60 percent respondents claimed that both father and mother have the responsibility of child's education, 23 percent respondents claimed that father have the responsibility of child's education, 17 percent respondents claimed that both mother and mother have the responsibility of child's education. The result of this table shows that both mother as well as father is responsible for the education of children. This table relates with the objective No.1 impact of modernization on both duties of male and females.

Table 4 Percentage distribution of respondents regarding to their housework hesitation.

\begin{tabular}{|c|c|c|}
\hline $\begin{array}{c}\text { Males have no hesitation } \\
\text { to do housework }\end{array}$ & Frequency & Percent \\
\hline Yes & 73 & 73 \\
\hline No & 27 & 27 \\
\hline Total & 100 & 100 \\
\hline
\end{tabular}

This table explains that 73 percent of respondents claimed that they have no hesitation to housework, 27 percent respondents claimed that they feel hesitation to do housework. The result of this table shows that modernization has changed traditional gender roles and now male have no hesitation to do house work.

Table 5 Percentage distribution of respondents regarding to the budget of home.

\begin{tabular}{|c|c|c|}
\hline Budget of home & Frequency & Percent \\
\hline Husband-Male & 21 & 21 \\
\hline Wife-Female & 31 & 31 \\
\hline Both & 48 & 48 \\
\hline Total & 100 & 100 \\
\hline
\end{tabular}

This table explains that 48 percent of respondent claimed that both male and female male make the budget of home, 31 percent of respondent claimed that female make the budget of home, 21 percent of respondent claimed that both male and makes the budget of home. The result shows that females also contribute in economic decision. This table relates with the objective No.3 influence of modernization on decision making.

Table 6 Percentage distribution of respondents regarding the choice of dressing style of their children.

\begin{tabular}{|c|c|c|}
\hline $\begin{array}{c}\text { Choice of children } \\
\text { dressing style }\end{array}$ & Frequency & Percent \\
\hline Yes & 6 & 6 \\
\hline No & 64 & 64 \\
\hline Do not know & 30 & 30 \\
\hline Total & 100 & 100 \\
\hline
\end{tabular}


This table shows that 64 percent of respondents claimed that their children do not wear the dress according to their choice, 30 percent of respondent claimed that they do not know about the choice of dressing style of their children , 6 percent of respondent claimed that their children wear the dress according to their choice. The result of this table shows that majority of respondents is not interested in choice of dressing style of their children. This table relates with the objective No. 2 influence of modernization on the socialization of young family members.

Table 7 Percentage distribution of respondents regarding the contradiction between dressing style of children and parents.

\begin{tabular}{|c|c|c|}
\hline $\begin{array}{c}\text { Contradiction in dressing } \\
\text { Style }\end{array}$ & Frequency & Percent \\
\hline Yes & 39 & 39 \\
\hline No & 61 & 61 \\
\hline Total & 100 & 100 \\
\hline
\end{tabular}

This table shows that 61 percent of respondents claimed that there is no contradiction between the dressing style of children and parents in their family, 39 percent respondents claimed that there is contradiction between dressing style of parents and children in their family. The result of this table shows that that child's are free for the choice of their dressing style. This table relates with the objective No2. Influence of modernization on the socialization of young family members.

Table 8 Percentage distribution of respondents regarding the extent to which their female family members have choice to marriage.

\begin{tabular}{|c|c|c|}
\hline $\begin{array}{c}\text { Females have choice to } \\
\text { marriage }\end{array}$ & Frequency & Percent \\
\hline To a great extent & 32 & 32 \\
\hline To some extent & 43 & 43 \\
\hline Not at all & 25 & 25 \\
\hline Total & 100 & 100 \\
\hline
\end{tabular}

This table shows that 43 percent respondents claimed that their female family members have choice to marriage to some extent, 32 percent of respondents claimed that their female family members have choice to marriage to a great extent, while the remaining 25 percent respondents claimed that their female family members $f$ have no choice to marriage. The result shows now females have choice to marriage at some extent while in the past they have no access. This table relates with the objective No.3 influence of modernization on decision making.

Table 9 Percentage distribution of respondents regarding the extent to which their male family members have choice to marriage.

\begin{tabular}{|c|c|c|}
\hline $\begin{array}{c}\text { Male have choice to } \\
\text { marriage }\end{array}$ & Frequency & Percent \\
\hline To a great extent & 70 & 70 \\
\hline To some extent & 30 & 30 \\
\hline Total & 100 & 100 \\
\hline
\end{tabular}

This table shows that 70 percent of respondents claimed that their male family members have choice to marriage to great extent, while the remaining 30 percent of respondents said that their male family members have choice to marriage to some extent. The result shows that male have choice to marriage. This table relates with the objective No.3 influence of modernization on decision making, 
Table 10 Percentage distributions of respondents regards to their ideas about females power for marriage decision.

\begin{tabular}{|c|c|c|}
\hline $\begin{array}{c}\text { Females have upper hand } \\
\text { for marriage decision }\end{array}$ & Frequency & Percent \\
\hline Yes & 13 & 13 \\
\hline No & 87 & 87 \\
\hline Total & 100 & 100 \\
\hline
\end{tabular}

This table shows that 87 percent of respondents consider that females have no upper hand for marriage decision, 13 percent respondents claimed that females have upper hand for marriage decision. The result shows that females have no upper hand for marriage decision. This table relates with the objective No.3 influence of modernization on decision making.

Table 11 Percentage distribution of respondents regards to their ideas that females become more sensitive for child care.

\begin{tabular}{|c|c|c|}
\hline $\begin{array}{c}\text { Females become more } \\
\text { sensitive for child-care }\end{array}$ & Frequency & Percent \\
\hline Yes & 51 & 51 \\
\hline No & 49 & 49 \\
\hline Total & 100 & 100 \\
\hline
\end{tabular}

This table shows that 51 percent of respondents consider that women's become more sensitive for child care, 49 percent of respondents consider that women are not more sensitive for child-care. This table relates with the objective No.3 influence of modernization on decision making.

Table 12 Percentage distribution of respondents regarding that family female gets treatment from male doctor.

\begin{tabular}{|c|c|c|}
\hline $\begin{array}{c}\text { Female treatment from } \\
\text { Male doctor }\end{array}$ & Frequency & Percent \\
\hline Yes & 98 & 98 \\
\hline No & 2 & 2 \\
\hline Total & 100 & 100 \\
\hline
\end{tabular}

This table shows that 98 percent of respondents claimed that their family female get treatment from male doctor, 2 percent of respondent claimed that their family female does not get treatment from male doctor. The result shows that females get treatment from male doctor without any hesitation. This table relates with the objective No.3 influence of modernization on decision making.

Table 13 Percentage description of respondents regarding to responsibility of child's health.

\begin{tabular}{|c|c|c|}
\hline $\begin{array}{c}\text { Responsible for child } \\
\text { health }\end{array}$ & Frequency & Percentage \\
\hline Mother & 38 & 38 \\
\hline Father & 10 & 10 \\
\hline Both & 52 & 52 \\
\hline Total & 100 & 100 \\
\hline
\end{tabular}

This table shows that 52 percent of respondents claimed that both mother and father are responsible for child health, 38 percent said that mother is responsible for child health, 10 percent said that both father and father is responsible for child's health. The result shows that both mother and father are responsible for child health. This table relates with the objective No.3 influence of modernization on decision making. 
Table 14 Percentage of respondents regarding to ideas about the extent to which modernization has changed gender roles.

\begin{tabular}{|c|c|c|}
\hline $\begin{array}{c}\text { Modernization has } \\
\text { changed } \\
\text { Gender roles }\end{array}$ & Frequency & Percent \\
\hline To a great extent & 69 & 69 \\
\hline To some extent & 31 & 31 \\
\hline Total & 100 & 100 \\
\hline
\end{tabular}

This table shows that 69 percent of respondents said that modernization has changed gender roles to a great extent, 41 percent of respondents said that modernization has changed gender roles to some extent. The result shows that modernization has changed traditional gender roles.

\section{Hypothesis}

Modernization through higher educational levels is changing gender roles.

\section{Null Hypothesis}

Modernization through higher educational levels is not changing gender roles.

\section{Explanation}

The result shows that gender roles are changing to a great extent due to modernization, and the result shows that the hypothesis is accepted.

\section{CONCLUSION}

According o the results of my research modernization has changed gender roles, and modernization has affected the decision making, Socialization of children and household duties.

1 The results of the above table shows that modernization has influence the males and females education and now females are also preferred for higher education.

2 The results of the above table shows that modernization has influence the pattern of marriage decision in family and now females have also choice to marriage decision.

3 The results of the above table shows that majority of people show their opinion that females should be given decision power.

4 The results of the above table shows that modernization has influence the female's traditional gender roles and females are going beyond their traditional gender roles.

5 The results of the above table shows that Majority of people show their opinion that modernization have changed gender roles at high extent. Modernization plays a big part in changing traditional gender roles.

\section{References}

[1] Crompton, Brockman and Lyonette .2005. Attitudes Women's Employment and the Domestic Division of Labour: Work, Employment and Society: 213-2

[2] Cristina Carpinelli .2009. Gender-roles http://en.allexperts.com/q/Sociology-sss

[3] Chukwuma .2003. Western education's impact on Northern Igbo gender roles in Nsukka Nigeria

[4] Durkheim, E. (1962). The rules of sociological method. New York, NY: Free Press. (Original work published 1895)

[5] Fouad, Daad. 2003. Family Structural Change and Women Participation in Decision Making within Household. www.erf.eg/html/blabor4.pdf 
[6] Mansell, R \& and Wehn, U. 1998. Knowledge Societies: Information Technology for Sustainable Development. New York: Oxford University Press.

[7] TREAS, Judith and Eric WIDMER 2000. Married Women's Employment over the Life Course: Attitudes in Cross-National Perspective. Social Forces, 79: 1409-1436.

[8] Inglehart, Ronald and Norris Pippa.2003. Rising Tide: Gender Equality and Cultural Change Around the World. New York and Cambridge: Cambridge University Press.

[9] Mukai, Motonobu 2004 B. Modernization and divorce In Japan. Marshall University, Thesis submitted to the Graduate College of Marshall University. Master of Arts in Sociology.

[10] Wirth, Louis.1938. Urbanism a way of life. Amercian journal of sociology, 37(july):49-60. 